\title{
MENINGKATKAN KAPASITAS BELAJAR ANAK USIA DINI MELALUI PEMBELAJARAN INTERAKTIF KREATIF DAN EDUKATIF
}

\author{
Dudung Priatna ${ }^{1}$
}

\begin{abstract}
Abstrak
Kapasitas belajar merupakan kemampuan potensial yang dimiliki anak dalam memenuhi kebutuhan dan permasalahan hidupnya. Selain itu kapasitas belajar (inteligensi) sebagai keahlian untuk memecahkan masalah serta kemampuan untuk beradaptasi dan belajar dari pengalaman hidup sehari-hari. Ciri utama perkembangan masa anak usia dini terletak pada aspek fisik, intelektual, dan emosional yang ditandai dengan: (1) pertumbuhan hasrat ingin tahu, (2) perkembangan minat, (3) pembentukan karakter, (4) pembentukan kepribadian, (5) perkembangan sosial, (6) perkembangan otak, dan (7) perkembangan bahasa. Lingkungan belajar yang kondusif ditunjang dengan sarana prasarana yang lengkap memungkinkan seluruh anak untuk beraktivitas sesuai dengan rencana kegiatan belajar. Proses belajar yang interaktif, kreatif dan edukatif memunculkan seluruh kemampuan anak terutama dalam berkomunikasi memunculkan rasa aman pada diri anak serta berimplikasi hasil belajar yang maksimal. Interaksi belajar yang terstruktur dengan baik berimplikasi meningkatkan potensi anak berupa komunikasi lisan dan tulisan. Permainan yang diberikan (kreatif dan edukatif) seperti eksplorasi dan investigasi matematika akan mengembangkan serta melatih sensori motorik anak. Bersamaan dengan itu, diperkenalkan budi pekerti (edukatif) demi pembentukan karakter. Kegiatan anak (interaktif dan kreatif) dengan permainan yang sarat rangsangan bertujuan menyeimbangkan perkembangan otak kiri dan otak kanan. Otak kiri berhubungan dengan kemampuan berlogika, sedangkan otak kanan berkaitan dengan kemampuan berimajinasi. Melalui kegiatan permainan anak dapat memahami konsep ruang dan waktu serta dapat memperkirakan kemungkinan urutan suatu peristiwa yang terjadi di sekitarnya. Aktivitas anak melakukan kegiatan (interaktif, kreatif dan edukatif) melalui daya abstraksi, apresiasi serta ketelitian yang tinggi sehingga berkreatifitas dan berimajinasi dalam menciptakan sesuatu secara spontan.
\end{abstract}

Kata Kunci : Kapasitas Belajar, Anak Usia Dini, Pembelajaran Kreatif Edukatif

\section{A. PENDAHULUAN}

Kapasitas belajar merupakan kemampuan potensial yang dimiliki anak dalam memenuhi kebutuhan dan permasalahan hidupnya. Selain itu kapasitas belajar (inteligensi) sebagai keahlian untuk memecahkan masalah serta kemampuan untuk beradaptasi dan belajar dari pengalaman hidup sehari-hari (Juntika Nurihsan, 2014). Kapasitas belajar anak usia dini sehari-hari dikembangkan melalui berbagai kegiatan bermain dan eksplorasi. Kegiatan bermain anak usia dini sambil memanipulasi benda kongkrit merupakan strategi agar kapasitas belajarnya

\footnotetext{
${ }^{1}$ Dosen UPI Kampus Cibiru
} 
berkembang secara optimal. Kegiatan memanipulasi benda kongkrit dalam kegiatan kelompok sebagai upaya mengembangkan beberapa karakteristik anak.

Karakteristik anak dapat dideskripsikan sebagai berikut yaitu berpikir simbolik, egosentrisme, nalar, perolehan konsep, klasifikasi, kemampuan memproses informasi, kognisi sosial, dan keativitas.

Ciri utama perkembangan masa anak usia dini terletak pada aspek fisik, intelektual, dan emosional yang ditandai dengan: (1) pertumbuhan hasrat ingin tahu, (2) perkembangan minat, (3) pembentukan karakter, (4) pembentukan kepribadian, (5) perkembangan sosial, (6) perkembangan otak, dan (7) perkembangan bahasa. Peran orang tua menyediakan pengalaman bagi anak yang memacu hasrat ingin tahu dan menyiapkan pengetahuan dasar, pengalaman langsung dan trial and error sebagai sarana belajar utama anak dalam melakukan kegiatan yang pertama.

Menurut Piaget tahap perkembangan intelektual yaitu pra operasional (2-6 tahun) untuk anak usia dini serta tahap operasional konkret (7-12 tahun) untuk anak sekolah dasar. Konservasi (teridentifikasi keadaan anak siap untuk belajar matematika) yaitu konservasi bilangan, konservasi panjang dan konservasi isi. Kegiatan konservasi diperlukan anak dalam membangun pengetahuannya sehingga pendapat Piaget melandasi aliran konstruktivisme dalam belajar matematika dengan memposisikan guru sebagai fasilitator dan motivator selama kegiatan kelompok. Proses asimilasi dan akomodasi membawa anak dalam membangun pemahamannya serta teori ini merekomendasikan perlunya pengamatan terhadap tingkat perkembangan intelektual anak sebelum suatu bahan belajar matematika diberikan.

Lingkungan belajar yang kondusif ditunjang dengan sarana prasarana yang lengkap memungkinkan seluruh anak untuk beraktivitas sesuai dengan rencana kegiatan belajar. Proses belajar yang interaktif memunculkan seluruh kemampuan anak terutama dalam berkomunikasi memunculkan rasa aman pada diri anak serta berimplikasi hasil belajar yang maksimal. Interaksi belajar yang terstruktur dengan baik berimplikasi meningkatkan potensi anak berupa komunikasi lisan dan komunikasi tulisan.

Lingkungan yang kondusif serta suasana sekolah yang aman membuat anak selama proses belajar berkomunikasi melalui lembar kerja berupa kegiatan yang memunculkan aktivitas anak berupa eksplorasi, investigasi, dan mengkonstruks penalaran anak. Hasil kerja anak melalui lembar kerja (komunikasi tulisan) pada setiap akhir kegiatan dipresentasikan (komunikasi lisan) sehingga guru mengklarifikasi hasil kerja untuk meyakinkan atau meluruskan setiap jawaban. Produk hasil kerja anak merupakan representasi keberhasilan guru selama proses belajar dengan mengakomodasi seluruh komponen yang diperlukan untuk meningkatkan pemahaman (pengetahuan konseptual) anak melalui prosedur yang sistematis (keterampilan prosedural) sehingga anak yakin apa yang dikerjakannya.

Berdasarkan uraian diatas, tulisan ini akan membahas Meningkatkan Kapasitas Belajar Anak Usia Dini Melalui Pembelajaran Interaktif Kreatif dan Edukatif. 


\section{B. PEMBAHASAN}

\section{Karakteristik Anak Usia Dini}

Menurut Pamela (2004) perlakuan terhadap anak usia dini (usia kurang dari enam tahun atau sebelum masuk SD) sebaiknya lebih sarat dengan rangsangan berupa permainan, sebab dunia anak adalah dunia bermain. Permainan yang sesuai berupa gerakan, bunyi-bunyian, warna-warni, maupun suasana yang menyenangkan bagi anak tanpa banyak perintah. Selain itu permainan seperti memainkan gunting dan korek api, atau loncat dari meja ke kursi merupakan permainan yang dilarang karena membahayakan keselamatan.

Permainan yang diberikan seperti eksplorasi dan investigasi matematika akan mengembangkan serta melatih sensori motorik anak. Bersamaan dengan itu, diperkenalkan budi pekerti demi pembentukan karakter. Kegiatan anak dengan permainan yang sarat rangsangan bertujuan menyeimbangkan perkembangan otak kiri dan otak kanan. Otak kiri berhubungan dengan kemampuan berlogika, sedangkan otak kanan berkaitan dengan kemampuan berimajinasi.

Tujuan permainan matematika di pendidikan usia dini agar anak dapat mengetahui dasar-dasar pembelajaran berhitung dalam suasana yang menarik, aman, nyaman dan menyenangkan sehingga anak akan memiliki kesiapan dalam mengikuti pembelajaran matematika di sekolah dasar. Permainan matematika di pendidikan usia dini dikembangkan melalui pengamatan terhadap benda-benda konkret, gambar-gambar ataupun angka-angka yang terdapat disekitar anak sehingga dapat berpikir logis dan sistematis sejak dini. Anak usia dini dapat menyesuaikan dan melibatkan diri dalam kehidupan bermasyarakat yang dalam kesehariannya memerlukan keterampilan berhitung. Melalui kegiatan permainan anak dapat memahami konsep ruang dan waktu serta dapat memperkirakan kemungkinan urutan suatu peristiwa yang terjadi di sekitarnya.

Aktivitas anak melakukan kegiatan melalui daya abstraksi, apresiasi serta ketelitian yang tinggi sehingga berkreatifitas dan berimajinasi dalam menciptakan sesuatu secara spontan. Permainan matematika yang diberikan pada anak usia dini bermanfaat yaitu (1) membelajarkan anak berdasarkan konsep matematika yang benar, menarik dan menyenangkan, (2) menghindari ketakutan terhadap matematika sejak awal, dan (3) membantu anak belajar matematika secara alami melalui kegiatan bermain. Permainan matematika untuk anak usia dini membutuhkan waktu untuk mengeksplorasi dan menemukan konsep matematika dengan cara mereka sendiri dalam situasi dan lingkungan yang mendukung, anak akan tumbuh menjadi individu yang memandang matematika sebagai bagian yang alami dan penting dalam kehidupan sehari-hari.

Peran guru sangat dibutuhkan dalam mengembangkan kegiatan belajar matematika di pendidikan usia dini agar membangun rasa keingintahuan anak secara alami tentang bentuk, ukuran, jumlah, dan konsep-konsep dasar dalam matematika. Aktivitas guru yang terencana akan mendorong kepercayaan diri anak untuk berpikir, bertanya, dan berbagi pengalaman tentang berbagai hal yang dialami anak. Belajar kelompok atau pembelajaran kooperatif sejalan dengan teori Vygotsky yang mengembangkan model konstruktivistik belajar mandiri Piaget menjadi belajar kelompok melalui teori ini anak dapat memperoleh pengetahuan konseptual dan 
keterampilan prosedural melalui kegiatan yang beraneka ragam dengan guru sebagai fasilitator. Pembelajaran berpanduan Lembar Kerja selama proses pembelajaran dirancang dengan fokus anak melakukan eksplorasi, investigasi dan mengkonstruk pemahaman sendiri tentang konsep yang dipelajari.

Aktivitas matematika yang direncanakan diperlukan guru dalam mempersiapkan bahan pembelajaran, sebab memiliki banyak cara diperlukan untuk membangun kemampuan berpikir, dan membawa anak berpikir matematika. Aktivitas yang direncanakan guru dalam memahami matematika seperti memotivasi anak penstrukturan pengetahuan, pengurutan topik, dan menambahkan materi pendukung.

\section{Teori Belajar Anak Usia Dini}

Menurut Piaget tahap perkembangan intelektual anak usia dini yaitu pra operasional (2-7 tahun). Konservasi (teridentifikasi keadaan anak siap untuk menerima materi pelajaran matematika) yaitu konservasi bilangan, konservasi panjang dan konservasi isi. Kegiatan konservasi diperlukan anak dalam membangun pengetahuannya sehingga pendapat Piaget melandasi aliran konstruktivisme dalam pembelajaran matematika dengan memposisikan guru sebagai fasilitator dan motivator selama kegiatan kelompok. Proses asimilasi dan akomodasi membawa anak dalam membangun pemahamannya serta teori ini merekomendasikan perlunya pengamatan terhadap tingkat perkembangan intelektual anak sebelum suatu bahan belajar matematika diberikan.

Bruner mengungkapkan bahwa proses pembelajaran sebaiknya anak diberi kesempatan untuk memanipulasi benda kongkrit (manipulatif material). Bruner mengemukakan bahwa proses pembelajaran anak melewati tiga tahapan yaitu (1) Enaktif, dalam tahap ini anak secara langsung terlibat memanipulasi objek kongkrit, (2) Ikonik, dalam tahap ini anak berhubungan dengan mental yang merupakan gambaran dari objek-objek yang dimanipulasikannya, dan (3) Simbolik, dalam tahap ini anak memanipulasi symbol-simbol atau lambang-lambang objek tertentu.

Kemampuan mental anak berkembang secara bertahap mulai dari yang sederhana ke yang rumit, mulai yang mudah ke yang sulit, mulai yang nyata atau konkret ke yang abstrak. Urutan tersebut dapat membantu anak untuk mengikuti pelajaran dan urutan bahan pelajaran terkait dengan umur anak. Teori ini berkaitan dengan perkembangan mental, yaitu kemampuan mental anak berkembang secara bertahap mulai dari sederhana ke rumit, mulai dari yang mudah ke yang sulit, dan mulai dari yang nyata atau konkret ke yang abstrak.

Menurut Van Hiele tahap perkembangan mental anak dalam belajar geometri melalui beberapa tahapan. Pertama, tahap pengenalan anak mulai belajar mengenal suatu bentuk geometri yang dilihatnya. Kedua, tahap analisis anak sudah mulai mengenal sifat-sifat yang dimiliki benda geometri yang diamati dan sudah mampu menyebutkan keteraturan yang terdapat pada benda geometri itu. Ketiga, tahap pengurutan anak sudah mulai mampu melakukan penarikan kesimpulan yang kita sebut berpikir deduktif tetapi kemampuan ini belum berkembang secara maksimal.

Visualisasi (pengenalan) kegiatan anak cenderung memanipulasikan model fisik sehingga kemampuannya perlu diarahkan pada mengurutkan, mengidentifikasi 
dan mendeskripsikan berbagai bangun geometri. Analisis kegiatan anak mulai dapat mengkaji sifat-sifat bangun, kemampuan mereka mulai mengarah ke klasifikasi bangun berdasarkan bentuk dan nama. anak sudah mampu mendefinisikan, mengukur, mengamati dan menyebutkan sifat-sifat bangun. Deduksi informal (pengurutan) anak mempunyai kemampuan menggunakan model-model untuk mencari sifat-sifat serta dapat bernalar deduktif secara informal.

\section{Pembelajaran Interaktif Kreatif dan Edukatif untuk Anak Usia Dini}

Permainan matematika di pendidikan anak usia dini dikembangkan dengan belajar interaktif, kreatif dan edukatif melalui pengamatan terhadap benda-benda konkret, gambar-gambar ataupun angka-angka yang terdapat disekitar anak sehingga dapat berpikir logis dan sistematis sejak dini. Anak usia dini dapat menyesuaikan dan melibatkan diri dalam kehidupan bermasyarakat yang dalam kesehariannya memerlukan keterampilan berhitung. Melalui kegiatan permainan yang interaktif, kreatif dan edukatif anak dapat memahami konsep ruang dan waktu serta dapat memperkirakan kemungkinan urutan suatu peristiwa yang terjadi di sekitarnya. Aktivitas anak melakukan kegiatan interaktif, kreatif dan edukatif melalui daya abstraksi, apresiasi serta ketelitian yang tinggi sehingga berkreatifitas dan berimajinasi dalam menciptakan sesuatu secara spontan.

Permainan matematika yang diberikan pada anak usia dini bermanfaat yaitu (1) membelajarkan anak berdasarkan konsep matematika yang benar, menarik dan menyenangkan (interaktif), (2) menghindari ketakutan terhadap matematika sejak awal (kreatif), dan (3) membantu anak belajar matematika secara alami melalui kegiatan bermain (edukatif). Permainan matematika untuk anak usia dini membutuhkan waktu untuk mengeksplorasi dan menemukan konsep matematika dengan cara mereka sendiri (kreatif) dalam situasi dan lingkungan yang mendukung (interaktif), anak akan tumbuh menjadi individu yang memandang matematika sebagai bagian yang alami dan penting dalam kehidupan sehari-hari (edukatif).

Pengalaman anak (interaktif, kreatif dan edukatif) dengan manipulatif material sebagai alat permainan matematika yang memiliki ciri khusus maupun yang terus menerus ada. Manipulatif material yang mempunyai ciri khusus adalah yang dapat dihitung seperti kue, mobil-mobilan, dan titik pada selembar kertas. Anak-anak dapat menggunakan balok-balok unit atau kubus-kubus untuk dihitung dan ditumpuk. Jenis lainnya seperti mata rantai berwarna, papan mainan, boneka permainan, manik-manik, guntingan gambar pada papan planel dan barang-barang magnetis.

Material yang terus menerus ada adalah barang yang tidak dihitung tetapi diukur dalam hal yang berhubungan dengan panjang, luas, tinggi, berat, isi (volume), kapasitas atau temperatur. Nilai perhitungan tinggi seorang anak, botol susu ditentukan dengan membandingkan dengan sebuah ukuran. Ketika anak membangun sebuah tower balok-balok tersebut tidak hanya berfungsi sebagai objekobjek yang memiliki ciri khusus akan tetapi juga unit-unit pengukuran. Jika anakanak menumpahkan air dari suatu tempat ke tempat lainnya menggunakan corong mereka mengembangkan ide-ide tentang kapasitas, isi, berat, dan massa (kreatif). Selain air atau pasir dapat juga dikembangkan kacang, beras atau butir peluru 
plastik menggantikan material yang terus menerus ada (catatan butir beras dapat dihitung tetapi dalam hal ini dianggap sebagai material yang terus menerus ada). Ketika anak bekerja dengan material yang memiliki ciri khusus dan terus menerus ada, mereka belajar untuk mengkomparasi kuantitas pada jumlah dan ukuran (interaktif dan edukatif).

Bekerja dan bermain dengan keragaman material yang berciri khusus dan material yang terus menerus ada mengembangkan kemampuan belajar dasar (interaktif dan kreatif). Penguraian dan pengklasifikasian, penserian dan pengurutan, urutan dan pemolaan adalah kemampuan dasar yang digunakan untuk semua mata pelajaran. Pengklasifikasian dapat menjadi yang pertama dan paling fundamental dalam kemampuan berpikir, anak-anak mengembangkan kemampuan pengklasifikasian atau pengelompokan kembali dengan prinsip kesamaan. Kesempatan untuk latihan yang bermacam-macam dan materi yang beragam (edukatif) dalam pengklasifikasian membantu anak-anak mengembangkan kefleksibelan berpikir dan mempelajari konsep-konsep.

Pengurutan dan penserian dapat diterapkan dengan menggunakan material baik yang berciri khusus maupun yang terus menerus ada. Material yang berciri khusus dihitung dan perangkatnya diurutkan dengan menggunakan bilangan, material yang terus menerus ada (tak dapat dihitung) diukur dan diserikan ataupun diletakkan dalam urutan berdasarkan panjang, tinggi atau berat. Pengklasifikasian didasarkan pada prinsip kesamaan sedangkan penserian didasarkan pada prinsip perbedaan. Kebermacaman pengalaman (interaktif, kreatif dan edukatif) akan membantu anak mendapatkan dan menemukan perbedaan-perbedaan.

Urutan adalah satu susunan atau kegiatan yang berguna (berarti) dan dapat dihubungkan dengan pengurutan (deret). Kegiatan dalam kelas dapat diurutkan dalam bentuk jadwal yang telah disusun sehingga anak-anak mengetahui bahwa urutan kegiatan sehari-hari adalah belajar dan istirahat. Pola didasarkan pada pengurutan; sebuah pola adalah satu urutan objek, kegiatan, atau gagasan yang berulang. Kemampuan untuk mengenali urutan dan pengulangan adalah kemampuan berpikir (kreatif) yang penting digunakan dalam bidang kurikulum. Pola-pola kata dan huruf digunakan oleh pembaca yang baik; permainan kata-kata atau macam-macam permainan kata lainnya didasarkan pada distorsi pola-pola kata yang biasa. Ketika bekerja (interaktif) dengan pola-pola beberapa anak mungkin membutuhkan bantuan dalam mengenal dimanakah setiap urutan dalam pemolaan dimulai dan berakhir.

Vygotsky menekankan pentingnya konteks sosial dalam pengembangan kemampuan berpikir anak (interaktif, kreatif dan edukatif). Lebih jauh ia menjelaskan bahwa bentuk-bentuk aktivitas mental yang tinggi diperoleh dari konteks sosial dan budaya tempat anak berinteraksi dengan teman-teman atau orang lain. Kegiatan dalam kelompok anak memanipulasi dan mempersepsi objek sesuai dengan dunianya, terlepas apakah objek itu sesuai dengan kenyataan atau fungsi objek tersebut.

Bruner mengungkapkan bahwa proses belajar interaktif, kreatif dan edukatif sebaiknya anak diberi kesempatan untuk memanipulasi benda kongkrit (manipulatif material). Bruner mengemukakan bahwa proses pembelajaran anak melewati tiga 
tahapan yaitu (1) Enaktif, dalam tahap ini anak secara langsung terlibat memanipulasi objek kongkrit, (2) Ikonik, dalam tahap ini anak berhubungan dengan mental yang merupakan gambaran dari objek-objek yang dimanipulasikannya, dan (3) Simbolik, dalam tahap ini anak memanipulasi symbol-simbol atau lambanglambang objek tertentu.

Kemampuan mental anak berkembang secara bertahap mulai dari yang sederhana ke yang rumit, mulai yang mudah ke yang sulit, mulai yang nyata atau konkret ke yang abstrak. Urutan tersebut dapat membantu anak untuk mengikuti pelajaran dan urutan bahan pelajaran terkait dengan umur anak. Teori ini berkaitan dengan perkembangan mental, yaitu kemampuan mental anak berkembang secara bertahap mulai dari sederhana ke rumit, mulai dari yang mudah ke yang sulit, dan mulai dari yang nyata atau konkret ke yang abstrak (interaktif, kreatif dan edukatif).

Tahap perkembangan mental anak menurut Van Hiele dalam belajar geometri (interaktif, kreatif dan edukatif) melalui beberapa tahapan. Pertama, tahap pengenalan anak mulai belajar mengenal (interaktif) suatu bentuk geometri yang dilihatnya. Kedua, tahap analisis anak sudah mulai mengenal sifat-sifat (edukatif) yang dimiliki benda geometri yang diamati dan sudah mampu menyebutkan keteraturan yang terdapat pada benda geometri itu. Ketiga, tahap pengurutan anak sudah mulai mampu melakukan penarikan kesimpulan (kreatif) yang kita sebut berpikir deduktif tetapi kemampuan ini belum berkembang secara maksimal.

Kegiatan memvisualisasi (pengenalan) anak cenderung memanipulasikan model fisik sehingga kemampuannya perlu diarahkan pada mengurutkan, mengidentifikasi dan mendeskripsikan berbagai bangun geometri. Analisis kegiatan anak (interaktif, kreatif dan edukatif) mulai dapat mengkaji sifat-sifat bangun, kemampuan mereka mulai mengarah ke klasifikasi bangun berdasarkan bentuk dan nama. anak sudah mampu mendefinisikan, mengukur, mengamati dan menyebutkan sifat-sifat bangun. Deduksi informal (pengurutan) anak mempunyai kemampuan menggunakan model-model untuk mencari sifat-sifat serta dapat bernalar deduktif secara informal.

\section{PENUTUP}

Kapasitas belajar anak usia dini sehari-hari dikembangkan melalui berbagai kegiatan bermain dan eksplorasi. Kegiatan bermain anak usia dini sambil memanipulasi benda kongkrit merupakan strategi agar kapasitas belajarnya berkembang secara optimal. Kegiatan memanipulasi benda kongkrit (kreatif) dalam kegiatan kelompok (interaktif) sebagai upaya mengembangkan beberapa karakteristik anak (edukatif).

Perlakuan terhadap anak usia dini (usia kurang dari enam tahun atau sebelum masuk SD) sebaiknya lebih sarat dengan rangsangan berupa permainan, sebab dunia anak adalah dunia bermain (belajar interaktif, kreatif dan edukatif). Permainan yang sesuai berupa gerakan, bunyi-bunyian, warna-warni, maupun suasana yang menyenangkan bagi anak tanpa banyak perintah. Selain itu permainan seperti memainkan gunting dan korek api, atau loncat dari meja ke kursi merupakan permainan yang dilarang karena membahayakan keselamatan. 
Kemampuan mental anak berkembang secara bertahap mulai dari yang sederhana ke yang rumit, mulai yang mudah ke yang sulit, mulai yang nyata atau konkret ke yang abstrak. Urutan tersebut dapat membantu anak untuk mengikuti pelajaran dan urutan bahan pelajaran terkait dengan umur anak. Teori ini berkaitan dengan perkembangan mental, yaitu kemampuan mental anak berkembang secara bertahap mulai dari sederhana ke rumit, mulai dari yang mudah ke yang sulit, dan mulai dari yang nyata atau konkret ke yang abstrak (belajar interaktif, kreatif dan edukatif).

\section{DAFTAR PUSTAKA}

Juntika Nurihsan. (2014). Pengembangan Kapasitas Belajar Siswa Melalui Bimbingan dan Hypnoconseling. Makalah Seminar Nasional Prodi Psikologi SPs UPI Tgl. 20 Februari 2014.

Kennedy dan Tipps. (1994). Guiding Children's Learning of Mathematics. Belmont: Wadsworth.

Pamela, CP. (2004). Rangsanglah Otak Anak dengan Bermain. Jakarta: HU Kompas.

Priatna, D. (2012). Pembentukan Karakter Siswa Dalam Pembelajaran Matematika SD Dengan Mengeksplorasi Topik Essensial. Prosiding Seminar Internasional Ke-3 UPI Kampus Cibiru

Samani, Muchlas dan MS Hariyanto. (2012). Konsep dan Model Pendidikan Karakter. Bandung: Remaja Rosdakarya.

Solehudin, M. (2004). Memfasilitasi Perkembangan Berpikir dan Kreativitas Anak Usia Dini. Jurnal Ilmu Pendidikan Pedagogia. Vol.2, No.1, April 2004.

Sumarmo, et. al. (2003). Kumpulan Makalah Lokakarya Pembelajaran Matematika Realistik. Bandung: Jurdikmat FPMIPA UPI.

Yuliani NS, et. al. (2004). Metode Pengembangan Kognitif. Jakarta: Penerbit Universitas Terbuka.

Windayana, Priatna, dan Kartika. (2012). Penggunaan Lembar Kerja Seting Komik Dalam Meningkatkan Prestasi Belajar Matematika Siswa SD. Laporan Penelitian Hibah UPI. 